\title{
Regulation of Protein Kinase $M \zeta$ Synthesis by Multiple Kinases in Long-Term Potentiation
}

\author{
Matthew Taylor Kelly, ${ }^{1,2}$ John Fonda Crary, ${ }^{1,2}$ and Todd Charlton Sacktor ${ }^{1}$ \\ ${ }^{1}$ Departments of Physiology, Pharmacology, and Neurology, and ${ }^{2}$ Graduate Program in Neural and Behavioral Sciences, The Robert F. Furchgott Center for \\ Neural and Behavioral Science, State University of New York Downstate Medical Center, Brooklyn, New York, 11203
}

\begin{abstract}
The persistent activity of protein kinase $\mathrm{M} \zeta(\mathrm{PKM} \zeta$ ) maintains synaptic long-term potentiation (LTP) and spatial memory, but the interactions between PKM $\zeta$ and the other protein kinases implicated in synaptic plasticity are unknown. During LTP, PKM $\zeta$ is rapidly synthesized from a PKM $\zeta$ mRNA that encodes a protein kinase $\mathrm{C} \zeta(\mathrm{PKC} \zeta)$ catalytic domain without a regulatory domain; thus, second messengers that activate full-length PKC isoforms are not required to stimulate PKM $\zeta$. Like other PKCs, however, $\operatorname{PKM} \zeta$ must be phosphorylated on its activation loop by phosphoinositide-dependent protein kinase-1 (PDK1) for optimal catalytic activity. Thus, two sequential steps are required for the persistent increased PKM $\zeta$ activity that maintains LTP: de novo synthesis of PKM $\zeta$ and phosphorylation of its activation loop. Here, using a panel of antisera to phosphorylated and nonphosphorylated sites on PKM $\zeta$, we show that PI3-kinase (phosphoinositide 3-kinase), CaMKII $\left(\mathrm{Ca}^{2+} /\right.$ calmodulin-dependent protein kinase II), MAPK (mitogen-activated protein kinase), PKA (protein kinase A), mTOR (mammalian target of rapamycin), all important for LTP induction, as well as preexisting PKM $\zeta$, regulate the new synthesis of PKM $\zeta$ during LTP. In contrast, PDK1 forms a complex with PKM $\zeta$ and maintains maximal phosphorylation of its activation loop. Thus, the two steps of PKM $\zeta$ formation serve separate functions in LTP: the initial regulated synthesis of PKM $\zeta$ is the site of convergence and integration for multiple kinases of induction, whereas the constitutive phosphorylation of PKM $\zeta$ by PDK1 initiates the persistent autonomous activity that sustains maintenance.
\end{abstract}

Key words: CaMKII; ERK; learning and memory; LTP; long-term potentiation; phosphoinositide 3-kinase; protein synthesis

\section{Introduction}

Multiple protein kinases are important for long-term potentiation (LTP), an activity-dependent, persistent increase in synaptic transmission critical for learning and memory storage (Bliss and Collingridge, 1993; Sweatt, 1999; Bliss et al., 2006; Pastalkova et al., 2006; Whitlock et al., 2006). Most of these kinases function in the transient induction phase of LTP that triggers synaptic potentiation and during initial learning and memory consolidation. In contrast, only a single protein kinase, the atypical protein kinase $\mathrm{C}(\mathrm{aPKC})$ isoform, protein kinase $\mathrm{M} \zeta(\mathrm{PKM} \zeta)$, has been shown to be critical during the maintenance of LTP that sustains potentiation and for the persistence of spatial memory storage in the hippocampus (Sacktor et al., 1993; Ling et al., 2002; Bliss et al., 2006; Pastalkova et al., 2006).

$\mathrm{PKM} \zeta$ can maintain LTP because the kinase is autonomously active in neural tissue (Sacktor et al., 1993) and, thus, able to persistently enhance synaptic strength (Ling et al., 2002, 2006; Serrano et al., 2005). This autonomous activity is due, in part, to the unique structure of PKM $\zeta$ (Hernandez et al., 2003). Most $\mathrm{PKC}$ isoforms consist of an $\mathrm{N}$-terminal regulatory domain, containing an autoinhibitory pseudosubstrate sequence and second

Received Dec. 26, 2006; revised Feb. 21, 2007; accepted Feb. 23, 2007.

This work was supported by National Institutes of Health Grants MH53576 and MH57068 to T.C.S.

Correspondence should be addressed to Dr. Todd C. Sacktor, Dept of Physiology and Pharmacology, Box 29, SUNY

Downstate Medical Center, 450 Clarkson Avenue, Brooklyn, NY 11203. E-mail: tsacktor@downstate.edu.

D01:10.1523/JNEUROSCI.5612-06.2007

Copyright $\odot 2007$ Society for Neuroscience $\quad$ 0270-6474/07/273439-06\$15.00/0 messenger-binding sites, and a C-terminal catalytic domain (Dekker et al., 1995; Newton, 2001). Under basal conditions, full-length PKC isoforms are inactive because the pseudosubstrate interacts with and inhibits the catalytic domain; second messengers, such as $\mathrm{Ca}^{2+}$ and diacylglycerol, stimulate PKCs by binding to the regulatory domain and causing a conformational change that releases this autoinhibition. $\mathrm{PKM} \zeta$, in contrast, is generated by synthesis from a brain-specific PKM $\zeta$ mRNA that encodes a $\zeta$ catalytic domain without a regulatory domain (Hernandez et al., 2003; Muslimov et al., 2004). Thus, the second messengers that activate full-length $\mathrm{PKC}$ isoforms are not required to stimulate $\mathrm{PKM} \zeta$.

A second mechanism, however, is also important for PKC activation. Each PKC has little or no activity without phosphorylation of the "activation loop" of its catalytic domain by phosphoinositide-dependent protein kinase-1 (PDK1) (Newton, 2003). This phosphorylation, which is important for the activity of most members of the AGC [protein kinase A (PKA)/PKG/ $\mathrm{PKC}$ ] superfamily of protein kinases, converts the kinase catalytic domain from an inactive conformation to an active conformation that can efficiently bind substrates (Biondi, 2004). The function of PDK1 phosphorylation, however, varies for the different AGC kinases. Phosphorylation of the full-length aPKCs by PDK1, for example, is important in their regulation by extracellular signals (Chou et al., 1998; Le Good et al., 1998). These signals activate aPKCs by first stimulating receptor-linked phosphoinositide 3 (PI3)-kinase, which produces the lipid second 
messenger, phosphatidylinositol-3,4,5-trisphosphate (Ptdins3,4,5-P3). Ptdins-3,4,5-P3 can then bind to both PDK1 and the regulatory domain of aPKC. A PDK1-docking site in the C-terminal of the aPKC catalytic domain may also facilitate interactions between the two kinases (Balendran et al., 2000a). Positioned together, PDK1 can then phosphorylate the aPKC catalytic domain on its activation loop (T410 in PKC $\zeta$ ), converting it from inactive to active conformation.

Because nonphosphorylated $\mathrm{PKM} \zeta$, like $\mathrm{PKC} \zeta$, is inactive (Balendran et al., 2000b; Smith and Smith, 2002) [or minimally active (Le Good and Brindley, 2004)], PKM $\zeta$ synthesized after tetanic stimulation must also undergo activation loop phosphorylation to acquire the autonomous activity that maintains LTP. The mechanism for this critical phosphorylation step is unknown. Because PI3-kinase is important for LTP induction (Kelly and Lynch, 2000; Sanna et al., 2002; Opazo et al., 2003), PDK1 phosphorylation of PKM $\zeta$ may be regulated in LTP, as has been shown for the phosphorylation of the full-length aPKCs, PKC $\zeta$ and $\mathrm{PKC} \iota / \lambda$, in other cellular contexts (Chou et al., 1998; Le Good et al., 1998). Alternatively, because PDK1 could directly bind PKM $\zeta$ (Balendran et al., 2000a), PDK1 phosphorylation of $\mathrm{PKM} \zeta$ might be constitutive in the brain and, thus, part of the maintenance mechanism that sustains LTP (Ling et al., 2002; Serrano et al., 2005; Pastalkova et al., 2006).

Here, using a panel of antisera to phosphorylated and nonphosphorylated sites on $\mathrm{PKM} \zeta$, we measured both the new synthesis and activation loop phosphorylation of $\mathrm{PKM} \zeta$ during LTP. We found that the initial synthesis of $\mathrm{PKM} \zeta$ is regulated by multiple kinases important for LTP induction, and is thus the convergent target of many signaling pathways in LTP. In contrast, the phosphorylation of $\mathrm{PKM} \zeta$ by PDK1 is constitutive, ensuring optimal PKM $\zeta$ activity to maintain LTP.

\section{Materials and Methods}

Animals. For all experiments, hippocampi of 18- to 30-d-old, male Sprague Dawley rats were removed after decapitation under halothaneinduced anesthesia, according to State University of New York Downstate Medical Center Animal Use and Care Committee standards.

Preparation of antisera and immunoblotting. Antisera to the phosphorylated state of T410 (pT410) was from Cell Signaling (Danvers, MA) (1:1000); C-terminal $\zeta$ antisera (1:100) was used as described previously (Sacktor et al., 1993). Phosphorylated T560 antiserum (pT560, 1:100) was generated by immunizing with a phosphopeptide (EPVQLPTDDC) conjugated to keyhole limpet hemocyanin (Lampire Biological Laboratories, Pipersville, PA). The phosphopeptide was injected intramuscularly into New Zealand rabbits and serum collected after 1-3 boosts at 1 month intervals. Antiserum to PDK1 (1:100) was a generous gift from Alex Toker (Department of Pathology, Beth Israel Deaconess Medical Center, Harvard Medical School, Boston, MA).

Immunoblots were performed as described previously (Sacktor et al., 1993). Briefly, purified $\mathrm{PKM} \zeta(\sim 100 \mathrm{ng})$ or total hippocampal protein $(10-15 \mu \mathrm{g})$ were subjected to SDS-PAGE. The proteins were transferred to nitrocellulose and blocked for $90 \mathrm{~min}$ in $1 \%$ bovine serum albumin and $1 \%$ hemoglobin in Tris- $\mathrm{HCl}, \mathrm{pH} 7.5$ (10 mm), $\mathrm{NaCl}(150 \mathrm{~mm})$, and Nonidet $(0.2 \%)$ (TBSN) (unless otherwise stated, reagents were from Sigma, St. Louis, MO). The nitrocellulose membrane was incubated in primary antisera overnight at $4^{\circ} \mathrm{C}$. The membrane was washed in TBSN and then incubated for 90 min with secondary antibody coupled to alkaline-phosphatase (1:2000). The blots were developed with 5-bromo4-chloro-3-indolyl phosphate/nitro blue tetrazolium, scanned, and analyzed with NIH Image.

Specificity of the phosphorylation state antisera was determined by both immunoblotting of phosphorylated and dephosphorylated PKM $\zeta$ (see Fig. $1 B$ ) and peptide competition. Peptide competition was performed by preincubating the primary antisera for $2 \mathrm{~h}$ at room temperature with $10 \mu \mathrm{g} / \mathrm{ml}$ of either phosphorylated or nonphosphorylated ver- sions of the immunizing peptide. Immunostaining of hippocampal $\mathrm{PKM} \zeta$ on immunoblot was blocked by the phosphorylated peptide but not by the nonphosphorylated peptide (data not shown).

Immunoprecipitation of $P K M \zeta$ and PDK1. Hippocampal tissue was homogenized at $4^{\circ} \mathrm{C}$ in $1 \mu \mathrm{l}$ per hippocampus (or $100 \mu \mathrm{l}$ per CA1 region for physiology experiments) of buffer containing the following: $50 \mathrm{~mm}$ Tris-HCl, pH 7.5, 1 mm EDTA, 1 mm EGTA, 0.1 mm phenylmethylsulfonyl fluoride, $5 \mathrm{~mm}$ benzamidine, aprotinin (17 kallikrein U/ml), 0.1 mu leupeptin, $1 \%$ phosphatase inhibitor cocktails 1 and 2, and 1\% NP40. Homogenization was with a \#19 Kontes glass tube and a Talboy 102 homogenizer, using 20 strokes at $60 \mathrm{rpm}$. Ten microliters of the homogenate was removed for determination of total protein by bicinchoninic acid assay (Pierce, Rockford, IL). The remaining homogenate was centrifuged at $13,000 \times g$ for $1 \mathrm{~h}$. The supernatant (S1) was precleared by adding normal goat serum conjugated to agarose beads (30 $\mu \mathrm{l}$ per $200 \mu \mathrm{l}$ $\mathrm{S} 1)$, nutating for $1 \mathrm{~h}$, and centrifuging at $13,000 \times g$ for $2 \mathrm{~min}$. Beads conjugated to a C-terminal aPKC antibody that recognizes both $\zeta$ and $\mathrm{PKC} \iota / \lambda$ (Hernandez et al., 2003) were added to the cleared supernatant $(20 \mu \mathrm{l} / 200 \mu \mathrm{l})$, nutated overnight, and centrifuged at $13,000 \times g$ for 2 min. For PDK1 immunoprecipitation, anti-PDK1 antisera was used at 1:200 dilution. The pelleted beads were washed three times in $200 \mu \mathrm{l}$ homogenization buffer, centrifuging at $13,000 \times g$ for 2 min between washes. The immunoprecipitated protein was then resuspended in $25 \mu \mathrm{l}$ of sample buffer, heated for $10 \mathrm{~min}$ at $90^{\circ} \mathrm{C}$, and assayed by immunoblot, as described above.

PKM $\zeta$ dephosphorylation. PKM $\zeta$ immunoprecipitated from one hippocampus was treated with $10 \mathrm{U}$ of calf alkaline intestinal phosphatase (New England Biolabs, Ipswich, MA) in a final volume of $50 \mu$ l, containing the immunoprecipitated protein in homogenization buffer, $100 \mathrm{~mm}$ $\mathrm{NaCl}$, and $10 \mathrm{~mm} \mathrm{MgCl}$. After $1 \mathrm{~h}$ at $37^{\circ} \mathrm{C}$, the reaction was stopped by the addition of sample buffer and heated for $10 \mathrm{~min}$ at $90^{\circ} \mathrm{C}$.

PDK1 phosphorylation of PKM $\zeta$. Hemagglutinin (HA)-tagged PKM $\zeta$ generated from Escherichia coli, which does not express PDK1, or PKM $\zeta$ generated from baculovirus/Sf9 cells (Ling et al., 2002), which was dephosphorylated (at $4^{\circ} \mathrm{C}$ to preserve its native conformation), were used as substrates for PDK1. The reaction was for $30 \mathrm{~min}$ at $30^{\circ} \mathrm{C}$ with $0-15 \mathrm{U}$ of PDK1 (Calbiochem, La Jolla, CA), $10 \mathrm{~mm} \mathrm{MgCl}_{2}, 1 \mathrm{~mm}$ $\beta$-mercaptoethanol, and $350 \mu \mathrm{M}$ Na-ATP (in $30 \mu \mathrm{l}$ final volume). The reaction was stopped by the addition of sample buffer and heated for 10 min at $90^{\circ} \mathrm{C}$. At the higher concentrations of PDK1 tested, the T410 phosphorylation of $\mathrm{PKM} \zeta$ at 10 and $30 \mathrm{~min}$ was equivalent, indicating saturation of the reaction (data not shown).

By comparing immunostaining with the C-terminal antiserum of a known quantity of recombinant $\mathrm{PKM} \zeta$, we calculated the amount of $\mathrm{PKM} \zeta$ in the hippocampus as $0.019 \pm 0.003 \%$ of total protein $(n=3)$, a level of expression comparable with a conventional PKC isoform in brain (Huang et al., 1987).

Hippocampal slice preparation, stimulation, and recording. Transverse hippocampal slices $(450 \mu \mathrm{m})$ were prepared as described previously (Hrabetova and Sacktor, 1996). Hippocampi were dissected, bathed in cold dissecting buffer, and sliced with a McIlwain tissue slicer. The dissecting buffer contained the following (in $\mathrm{mM}$ ): $125 \mathrm{NaCl}, 2.5 \mathrm{KCl}, 1.25$ $\mathrm{NaH}_{2} \mathrm{PO}_{4}, 26 \mathrm{NaHCO}_{3}, 11$ glucose, $10 \mathrm{MgCl}_{2}$, and $0.5 \mathrm{CaCl}_{2}$, bubbled with $95 \% \mathrm{O}_{2} / 5 \% \mathrm{CO}_{2}$, bringing the solution to $\mathrm{pH} 7.4$. After $30 \mathrm{~min}$ the slices were placed in an interface recording chamber $(2.1 \mathrm{ml}$ total volume; Fine Science Tools, Foster City, CA), prewarmed to $32.0 \pm 0.5^{\circ} \mathrm{C}$, and perfused at $0.5 \mathrm{ml} / \mathrm{min}$ with the saline solution containing $1.2 \mathrm{mM} \mathrm{MgCl}_{2}$ and $1.7 \mathrm{~mm} \mathrm{CaCl}_{2}$.

A bipolar platinum/iridium (80/20\%) electrode (Frederick Haer, Bowdoin, ME) was placed in CA1 stratum radiatum to evoke field EPSPs (fEPSPs) from Schaffer collateral-commissural/CA1 synapses. Field EPSPs were recorded using glass microelectrodes with a resistance of 3-8 $\mathrm{M} \Omega$, filled with the recording saline, and positioned $200 \mu \mathrm{m}$ from the stimulating electrodes. Current intensity of test stimuli $(20-40 \mu \mathrm{A}, 0.1$ ms duration) was set to produce one-third maximal fEPSPs (1.5-2.0 $\mathrm{mV}$ ). The frequency of test stimulation was every $15 \mathrm{~s}$. Baseline fEPSPs were recorded for at least $10 \mathrm{~min}$ to ensure stability of the responses. Data were collected and analyzed using Sigma 60 (GW Instruments, Somerville, MA). The slope of the fEPSP was measured between 10 and $50 \%$ of 

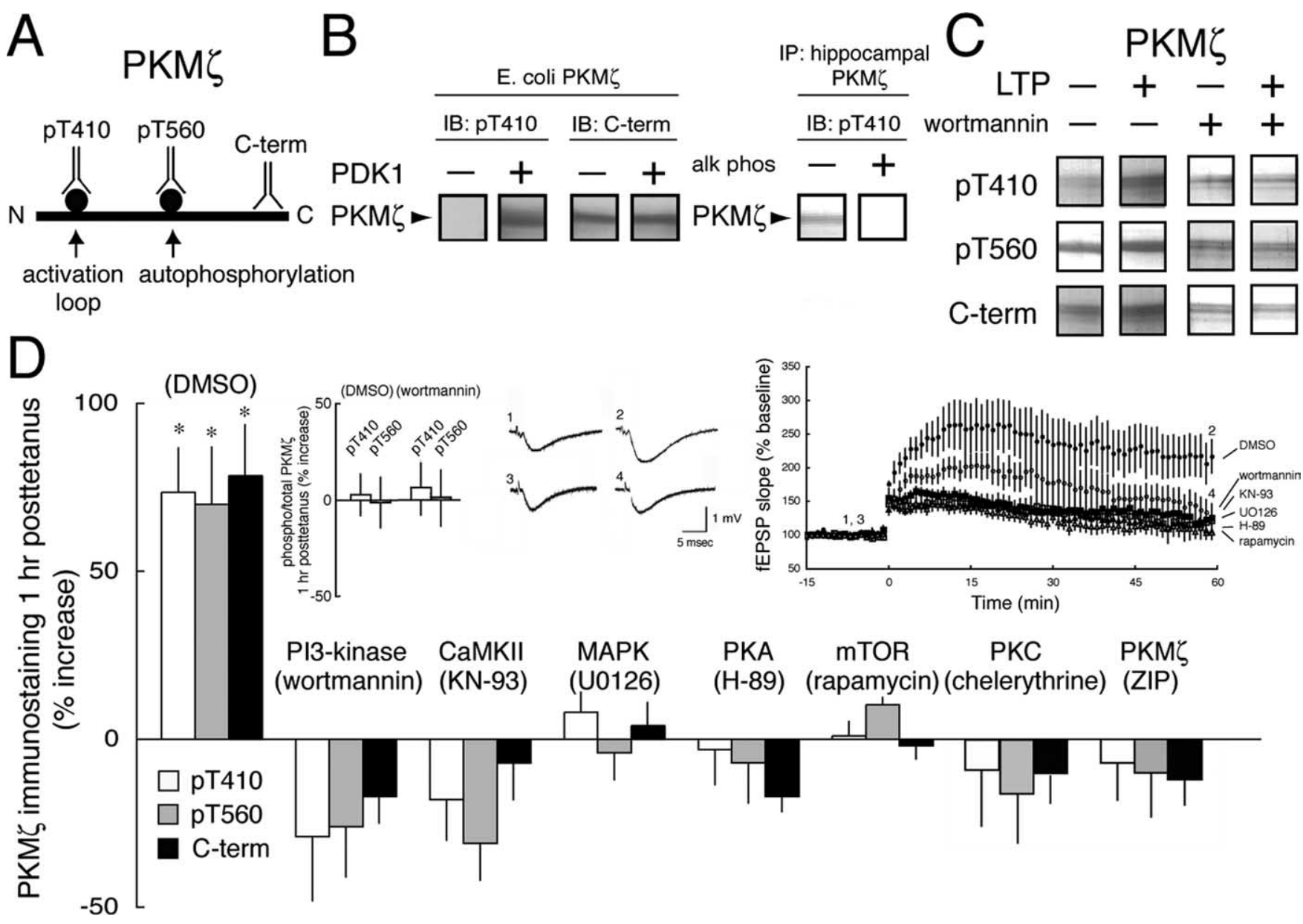

Figure 1. Synthesis, not phosphorylation of PKM $\zeta$ is the common target of multiple protein kinases in LTP induction. A, Illustration of the phosphorylation sites and C-terminal (C-term) epitope used for antisera production. B, Specificity of the pT410 antiserum. Left, pT410 antiserum recognizes E. coli-expressed PKM $\zeta$ after phosphorylation by PDK1; C-terminal antiserum recognizes both phosphorylated and nonphosphorylated PKM $\zeta$. Right, Exposure of hippocampal PKM $\zeta$ to calf intestinal phosphatase eliminates pT410 immunostaining. $C$, Representative experiment showing PKM $\zeta$ immunostaining with all three antisera increases after LTP and the blockade of the increases by application of the PI3-kinase inhibitor wortmannin. D, PKM $\zeta$ immunostaining with all three antisera increases in parallel $1 \mathrm{~h}$ after tetanization in the carrier DMSO (0.01\%). Asterisks denote $p<0.05$. Inhibitors of PI3-kinase, CaMKII, MAPK, PKA, mTOR, PKC, and PKM $\zeta$ (in 0.01\% DMS0) block the synthesis of PKM $\zeta(p>0.5$ between LTP and control slices for each inhibitor; $n=4)$, but do not affect the relative amounts of phospho-PKM $\zeta$ and total PKM $\zeta$. Insets, Left, Ratios of pT410/C-terminal and pT560/C-terminal immunostaining show no change in the proportion of phosphorylated PKM $\zeta$ after LTP and blockade of LTP by wortmannin. Middle, Representative fEPSPS for time points shown at the right (DMSO, 1, 2; wortmannin, 3, 4). Right, Time courses of experiments showing LTP in DMSO and blockade of LTP by kinase inhibitors ( $p>0.5$ between baseline responses and responses $1 \mathrm{~h}$ after tetanization for each inhibitor; $n=8$ ).

the initial phase of the fEPSP response. The tetanization protocol was four $100 \mathrm{~Hz}, 1 \mathrm{~s}$ trains, set at 75\% of the maximal fEPSP response (15-30 $\mu \mathrm{A}$ above the test stimuli current intensity), delivered at $20 \mathrm{~s}$ intertrain intervals (Scharf et al., 2002). Data were analyzed with Excel (Microsoft, Redmond, WA) and pClamp (version 9.0; Molecular Devices, Union City, CA). Test stimulation alone did not affect phospho-PKM $\zeta$ or total PKM $\zeta$ levels, compared with slices receiving no stimulation $(n=6 ; p>$ 0.05) (data not shown). Therefore, controls for LTP experiments were adjacent hippocampal slices bathed in the drug without test stimulation. Values are presented as mean \pm SEM.

\section{Results}

Multiple kinases converge to regulate $\mathrm{PKM} \zeta$ synthesis in LTP induction

We used three antisera to assay PKM $\zeta$ (Fig. 1A): a phosphospecific antiserum to its activation loop to assay its high activity conformation (pT410; for clarity, the amino-acid numbers of phosphorylation sites in $\mathrm{PKM} \zeta$ refer to the sequence of the fulllength $\mathrm{PKC} \zeta$ ), a second phosphospecific antiserum to the $\zeta$ autophosphorylation site used to assay catalytic competence (pT560) (Le Good et al., 1998), and an antiserum to the PKM $\zeta$ C-terminal to measure total $\mathrm{PKM} \zeta$. To confirm the phosphorylation-state specificity of the pT410 antisera, $\mathrm{PKM} \zeta$ produced from E. coli, which does not express PDK1, was immunostained with pT410 and C-terminal antisera (Fig. $1 B$, left). As expected, the C-terminal antiserum recognized the E. coli-expressed PKM $\zeta$, whereas the pT410 did not. After phosphorylation by exogenous PDK1, both antisera recognized the bacterially expressed PKM $\zeta$. Conversely, $\mathrm{PKM} \zeta$ immunoprecipitated from rat hippocampus with the C-terminal antiserum was recognized by the pT410 antiserum, and incubation with calf alkaline intestinal phosphatase eliminated pT410 immunoreactivity (Fig. $1 \mathrm{~B}$, right). Similar results were obtained with the pT560 antiserum (data not shown).

We then examined the changes in phospho-PKM $\zeta$ (measured by either pT410 or pT560 antisera immunostaining) and total $\mathrm{PKM} \zeta$ (measured by C-terminal antiserum immunostaining) during LTP (Fig. $1 D$, middle and right insets) $(p<0.01$, paired $t$ test between fEPSP responses, before and $1 \mathrm{~h}$ after tetanization in DMSO; $n=8$ ). The immunostaining for all three antisera increased in parallel, indicating that LTP caused an increase in total $\mathrm{PKM} \zeta$, but no change in the proportion of $\mathrm{PKM} \zeta$ that was phosphorylated (Fig. 1C,D) [two-way ANOVA showed a main effect of 
treatment $\left(F_{(7,72)}=16.892, p<0.0001\right.$; Tukey's post hoc test, $p<0.0001)$ whereas the main effect of antisera, comparing the increases in pT410, pT560, and C-terminal immunostaining to each other was not significant $\left(F_{(2,72)}=0.59 ; p>\right.$ 0.05); left inset shows no change in the ratio of phospho-PKM $\zeta$ to $\mathrm{PKM} \zeta$ during LTP].

We determined whether PI3-kinase, which activates full-length aPKCs by PDK1 phosphorylation of T410 (Chou et al., 1998; Le Good et al., 1998), increased the phosphorylation of $\mathrm{PKM} \zeta$ during LTP. As expected, the PI3-kinase inhibitor, wortmannin $(400 \mathrm{nM})$, blocked the induction of LTP (Fig. $1 D$, middle and right insets). We found that wortmannin prevented the synthesis of PKM $\zeta$ during LTP, but did not affect the relative amounts of phospho-PKM $\zeta$ (either pT410 or pT560) and total $\mathrm{PKM} \zeta$ (Fig. 1C,D, left insert) $(p>0.05)$.

Because PI3-kinase was critical for the synthesis of $\mathrm{PKM} \zeta$, we examined other pathways regulating translation in LTP. Mitogen-activated protein kinase (MAPK), which is in the same signaling pathway as calmodulin-dependent protein kinase II (CaMKII) (Giovannini et al., 2001) and PKA (Blitzer et al., 1998) in LTP induction, is critical for new, activitydependent protein synthesis (Kelleher et al., 2004). Inhibitors of MEK (MAPKextracellular signal-related kinase kinase) that activates MAPK (U0126, $20 \mu \mathrm{M})$, CaMKII (KN-93, $20 \mu \mathrm{M})$, and PKA (H-89, 20 $\mu \mathrm{M})$, all blocked LTP induction and PKM $\zeta$ synthesis (Fig. 1D). Because both PI3-kinase and MAPK can regulate the growthrelated increase in protein synthesis mediated by the mammalian target of rapamycin kinase (mTOR) (Gingras et al., 2001), we examined the effect of the mTOR inhibitor rapamycin (200 nM) and found that the agent also blocked $\mathrm{PKM} \zeta$ synthesis during LTP (Fig. 1D). Finally, in addition to its role in LTP maintenance, basal PKM $\zeta$ has been implicated in LTP induction (Sajikumar et al., 2005). Both the PKC inhibitor chelerythrine [ $2 \mu \mathrm{M}$, a low dose that may be selective toward PKM $\zeta$ (Ling et al., 2002)] and the $\mathrm{PKM} \zeta$ inhibitor $\zeta$-inhibitory peptide (ZIP; $1 \mu \mathrm{M}$ ) blocked the increase of PKM $\zeta$ in LTP (Fig. 1D). Although all of the inhibitors blocked PKM $\zeta$ synthesis and LTP induction, none affected the relative amounts of phospho-PKM $\zeta$ and total PKM $\zeta$ (Fig. 1D) $(p>0.5)$.

\section{Constitutive phosphorylation of the PKM $\zeta$ activation loop}

These results indicate that, although multiple signaling pathways of LTP induction regulate the synthesis of PKM $\zeta$, the phosphorylation state of PKM $\zeta$ before and after LTP is equivalent and not affected by any of the inhibitors. This suggests that activation loop phosphorylation of $\mathrm{PKM} \zeta$ might be constitutive, perhaps through a direct interaction between $\mathrm{PKM} \zeta$ and PDK1, as has been described in vitro (Balendran et al., 2000a). Consistent with this notion, we found that immunoprecipitation of $\mathrm{PKM} \zeta$ from hippocampus coprecipitated PDK1 (Fig. 2A, left), and, conversely, immunoprecipitation of PDK1 coprecipitated $\mathrm{PKM} \zeta$
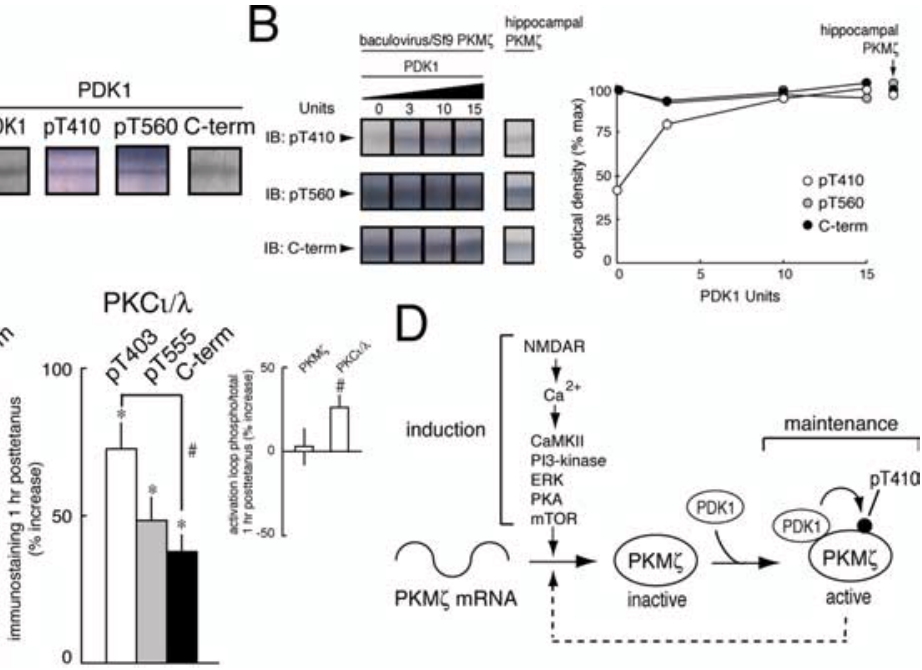

phosphorylation of PKM $\zeta$ by PDK1. $\boldsymbol{A}$, PKM $\zeta$ and PDK1 form a complex in hippocampal tissue. Left, Immunoprecipitation of PKM $\zeta$ from hippocampus coprecipitates PDK1; right, immunoprecipitation of PDK1 from hippocampus 列 0.05. D, Illustration of the biochemical pathways of LTP induction and maintenance. In induction, postsynaptic NMDAR acticonstitutively active PDK1 and is maximally phosphorylated on T410 to generate the autonomous activity maintaining LTP. PKM $\zeta$ may form a positive feedback loop to sustain increases in its synthesis during maintenance (dashed line).

(Fig. 2A, right). Because PDK1 activity does not require second messenger stimulation (Biondi, 2004), the interaction between the two kinases in brain may result in maximal phosphorylation of PKM $\zeta$. To quantify the phosphorylation of $\mathrm{PKM} \zeta$, we compared the phospho/total immunostaining of recombinant $\mathrm{PKM} \zeta$ that had been maximally phosphorylated by PDK1 to that of hippocampal PKM $\zeta$ (Fig. 2B). We found that the phosphorylation states of maximally phosphorylated recombinant $\mathrm{PKM} \zeta$ and hippocampal $\mathrm{PKM} \zeta$ were equivalent.

These results indicate that brain $\mathrm{PKM} \zeta$ is constitutively phosphorylated by PDK1. To determine whether this mechanism is specific to $\mathrm{PKM} \zeta$, we compared the phosphorylation of $\mathrm{PKM} \zeta$ during LTP with that of the other aPKC isoform expressed in the hippocampus, the full-length PKCı/ $\lambda$ (Hernandez et al., 2003), which is also activated after tetanization (Sacktor et al., 1993; Osten et al., 1996). Whereas again we found that the relative amounts of phosphorylated and total $\mathrm{PKM} \zeta$ remained constant after LTP (Fig. $2 C$, left and inset) $(p>0.05)$, the relative amount of activation loop phosphorylation to total level of $\mathrm{PKC} \iota / \lambda$ increased, indicating regulated phosphorylation (Fig. $2 C$, right and inset) $(p<0.05)$. Immunostaining for total $\mathrm{PKC} \iota / \lambda$ also increased after LTP, relative to control $(p<0.005)$, consistent with previous results (Osten et al., 1996).

\section{Discussion}

Here, we found that the two sequential steps for the formation of autonomously active $\mathrm{PKM} \zeta$, protein synthesis and activation loop phosphorylation, serve distinct functions in the transition from the induction to maintenance of LTP (Fig. 2D). The pri- 
mary site of the regulation of PKM $\zeta$ formation in LTP induction is its initial, presumably rate-limiting step, as is commonly observed in the regulatory control of metabolic pathways. In contrast, the subsequent reaction, activation loop phosphorylation, is constitutive, thus ensuring that the newly synthesized kinase is fully converted into its maximally active state to maintain LTP.

Combined with the previous finding that actin filament formation also regulates PKM $\zeta$ synthesis in LTP induction (Kelly et al., 2007), our results indicate that PKM $\zeta$ synthesis is the convergent target of many signaling pathways in LTP. These pathways likely regulate the increased translation of $\mathrm{PKM} \zeta$ from preexisting $\mathrm{PKM} \zeta \mathrm{mRNA}$, rather than increased transcription, because PKM $\zeta$ message levels do not change $1 \mathrm{~h}$ posttetanization (S. Kremlev and M. Kelly, personal communication) and metabolic labeling of $\mathrm{PKM} \zeta$ protein increases within minutes after tetanization, too rapid for new transcription of the $100 \mathrm{~kb} \mathrm{PKM} \zeta$ preRNA (Hernandez et al., 2003). Our results do not exclude the possibility that other proteins that function either in parallel with or downstream of PKM $\zeta$ may also be sites of convergent translational regulation (Kelleher et al., 2004). A trend toward a decrease in PKM $\zeta$ after LTP with some of the inhibitors (Fig. 1D) suggests that proteolytic degradation of the kinase may also be increased after strong afferent synaptic stimulation (Fonseca et al., 2006; Hou et al., 2006; Karpova et al., 2006).

The requirement of basal $\mathrm{PKM} \zeta$ activity for the synthesis of new PKM $\zeta$ during LTP suggests a positive feedback loop (Fig. $2 D$, dashed line) that may be important for the persistent increased PKM $\zeta$ activity that maintains in vivo LTP for at least $1 \mathrm{~d}$ and sustains spatial memory for up to 1 month (Pastalkova et al., 2006). Additional work will be required to determine whether this positive feedback loop is necessary and sufficient for these sustained effects of PKM $\zeta$.

Whereas $\mathrm{PKM} \zeta$ synthesis is the final common target of many signaling pathways in LTP induction, the constitutive activation loop phosphorylation of $\mathrm{PKM} \zeta$ represents the beginning of the biochemical mechanism of LTP maintenance (Fig. 2D). This constitutive phosphorylation of PKM $\zeta$ by PDK1 during LTP is in contrast to the regulated phosphorylation of the full-length aPKC isoforms, which is important for their stimulation by growth factors (Chou et al., 1998; Le Good et al., 1998) and hormones, particularly insulin (Standaert et al., 1997). Indeed, the constitutive activation loop phosphorylation of $\mathrm{PKM} \zeta$ appears similar to the PDK1 phosphorylation of the conventional/novel PKC isoforms (cPKC/nPKCs), which occurs immediately after their synthesis (Newton, 2003; Biondi, 2004). The interaction between PDK1 and c/nPKCs, however, is only transient and serves to make the $\mathrm{c} / \mathrm{nPKC}$ competent for subsequent regulation by second messengers. In contrast, the interaction between PDK1 and $\mathrm{PKM} \zeta$ in brain is stable and results in maximal phosphorylation and activity of PKM $\zeta$ for its persistent function. Although it is possible that nonphosphorylated $\mathrm{PKM} \zeta$ may be rapidly degraded and therefore undetected by our immunoblot assay, this may not be the case because full-length $\mathrm{PKC} \zeta$ appears to be stable without activation-loop phosphorylation (Balendran et al., 2000b; Le Good and Brindley, 2004).

Thus, the persistent activity of $\mathrm{PKM} \zeta$ that maintains LTP is generated by the elimination of the two essential mechanisms of $\mathrm{PKC}$ regulation. The standard regulation by second messengers is eliminated by the deletion of the $\zeta$ regulatory domain from the translation product of PKM $\zeta$ mRNA (Hernandez et al., 2003). Here, we show that regulated activation loop phosphorylation, critical for the stimulation of other aPKC isoforms, is eliminated by the constitutive binding and phosphorylation of PDK1. These unique properties allow $\mathrm{PKM} \zeta$ to be the specific protein kinase maintaining memory storage (Bliss et al., 2006; Pastalkova et al., 2006).

\section{References}

Balendran A, Biondi RM, Cheung PC, Casamayor A, Deak M, Alessi DR (2000a) A 3-phosphoinositide-dependent protein kinase-1 (PDK1) docking site is required for the phosphorylation of protein kinase $\mathrm{C} \zeta$ (PKC $\zeta)$ and PKC-related kinase 2 by PDK1. J Biol Chem 275:20806-20813.

Balendran A, Hare GR, Kieloch A, Williams MR, Alessi DR (2000b) Further evidence that 3-phosphoinositide-dependent protein kinase-1 (PDK1) is required for the stability and phosphorylation of protein kinase $\mathrm{C}$ (PKC) isoforms. FEBS Lett 484:217-223.

Biondi RM (2004) Phosphoinositide-dependent protein kinase 1, a sensor of protein conformation. Trends Biochem Sci 29:136-142.

Bliss TV, Collingridge GL (1993) A synaptic model of memory: long-term potentiation in the hippocampus. Nature 361:31-39.

Bliss TV, Collingridge GL, Laroche S (2006) Neuroscience. ZAP and ZIP, a story to forget. Science 313:1058-1059.

Blitzer RD, Connor JH, Brown GP, Wong T, Shenolikar S, Iyengar R, Landau EM (1998) Gating of CaMKII by cAMP-regulated protein phosphatase activity during LTP. Science 280:1940-1942.

Chou MM, Hou W, Johnson J, Graham LK, Lee MH, Chen CS, Newton AC, Schaffhausen BS, Toker A (1998) Regulation of protein kinase C zeta by PI 3-kinase and PDK-1. Curr Biol 8:1069-1077.

Dekker LV, Palmer RH, Parker PJ (1995) The protein kinase C and protein kinase $\mathrm{C}$ related gene families. Current Opinion Structural Biol 5:396-402.

Fonseca R, Vabulas RM, Hartl FU, Bonhoeffer T, Nagerl UV (2006) A balance of protein synthesis and proteasome-dependent degradation determines the maintenance of LTP. Neuron 52:239-245.

Gingras AC, Raught B, Sonenberg N (2001) Control of translation by the target of rapamycin proteins. Prog Mol Subcell Biol 27:143-174.

Giovannini MG, Blitzer RD, Wong T, Asoma K, Tsokas P, Morrison JH, Iyengar R, Landau EM (2001) Mitogen-activated protein kinase regulates early phosphorylation and delayed expression of $\mathrm{Ca}^{2+} /$ calmodulindependent protein kinase II in long-term potentiation. J Neurosci 21:7053-7062.

Hernandez AI, Blace N, Crary JF, Serrano PA, Leitges M, Libien JM, Weinstein G, Tcherapanov A, Sacktor TC (2003) Protein kinase M $\zeta$ synthesis from a brain mRNA encoding an independent protein kinase $\mathrm{C} \zeta$ catalytic domain. Implications for the molecular mechanism of memory. J Biol Chem 278:40305-40316

Hou L, Antion MD, Hu D, Spencer CM, Paylor R, Klann E (2006) Dynamic translational and proteasomal regulation of fragile $\mathrm{X}$ mental retardation protein controls mGluR-dependent long-term depression. Neuron 51:441-454.

Hrabetova S, Sacktor TC (1996) Bidirectional regulation of protein kinase $\mathrm{M} \zeta$ in the maintenance of long-term potentiation and long-term depression. J Neurosci 16:5324-5333.

Huang FL, Yoshida Y, Nakabayashi H, Huang K-P (1987) Differential distribution of protein kinase $\mathrm{C}$ isozymes in the various regions of brain. J Biol Chem 262:15714-15720.

Karpova A, Mikhaylova M, Thomas U, Knopfel T, Behnisch T (2006) Involvement of protein synthesis and degradation in long-term potentiation of Schaffer collateral CA1 synapses. J Neurosci 26:4949-4955.

Kelleher RJ, Govindarajan A, Jung HY, Kang H, S. T (2004) Translational control by MAPK signaling in long-term synaptic plasticity and memory. Cell 116:467-479.

Kelly A, Lynch MA (2000) Long-term potentiation in dentate gyrus of the rat is inhibited by the phosphoinositide 3-kinase inhibitor, wortmannin. Neuropharmacology 39:643-651.

Kelly MT, Yao Y, Sondhi R, Sacktor TC (2007) Actin polymerization regulates the synthesis of PKM $\zeta$ in LTP. Neuropharmacology 52:41-45.

Le Good JA, Brindley DN (2004) Molecular mechanisms regulating protein kinase $C \zeta$ turnover and cellular transformation. Biochem J 378:83-92.

Le Good JA, Ziegler WH, Parekh DB, Alessi DR, Cohen P, Parker PJ (1998) Protein kinase $\mathrm{C}$ isotypes controlled by phosphoinositide 3-kinase through the protein kinase PDK1. Science 281:2042-2045.

Ling DS, Benardo LS, Serrano PA, Blace N, Kelly MT, Crary JF, Sacktor TC 
(2002) Protein kinase $M \zeta$ is necessary and sufficient for LTP maintenance. Nat Neurosci 5:295-296.

Ling DS, Benardo LS, Sacktor TC (2006) Protein kinase M $\zeta$ enhances excitatory synaptic transmission by increasing the number of active postsynaptic AMPA receptors. Hippocampus 16:443-452.

Muslimov IA, Nimmrich V, Hernandez AI, Tcherepanov A, Sacktor TC, Tiedge H (2004) Dendritic transport and localization of protein kinase

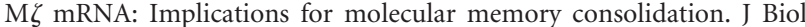
Chem 279:52613-52622.

Newton AC (2001) Protein kinase C: structural and spatial regulation by phosphorylation, cofactors, and macromolecular interactions. Chem Rev 101:2353-2364.

Newton AC (2003) Regulation of the ABC kinases by phosphorylation: protein kinase $\mathrm{C}$ as a paradigm. Biochem J 370:361-371.

Opazo P, Watabe AM, Grant SG, O’Dell TJ (2003) Phosphatidylinositol 3-kinase regulates the induction of long-term potentiation through extracellular signal-related kinase-independent mechanisms. J Neurosci 23:3679-3688.

Osten P, Valsamis L, Harris A, Sacktor TC (1996) Protein synthesis-dependent formation of protein kinase M $\zeta$ in LTP. J Neurosci 16:2444-2451.

Pastalkova E, Serrano P, Pinkhasova D, Wallace E, Fenton AA, Sacktor TC (2006) Storage of spatial information by the maintenance mechanism of LTP. Science 313:1141-1144.

Sacktor TC, Osten P, Valsamis H, Jiang X, Naik MU, Sublette E (1993) Persistent activation of the $\zeta$ isoform of protein kinase $\mathrm{C}$ in the maintenance of long-term potentiation. Proc Natl Acad Sci USA 90:8342-8346.
Sajikumar S, Navakkode S, Sacktor TC, Frey JU (2005) Synaptic tagging and cross-tagging: the role of protein kinase $M \zeta$ in maintaining long-term potentiation but not long-term depression. J Neurosci 25:5750-5756.

Sanna PP, Cammalleri M, Berton F, Simpson C, Lutjens R, Bloom FE, Francesconi W (2002) Phosphatidylinositol 3-kinase is required for the expression but not for the induction or the maintenance of long-term potentiation in the hippocampal CA1 region. J Neurosci 22:3359-3365.

Scharf MT, Woo NH, Lattal KM, Young JZ, Nguyen PV, Abel T (2002) Protein synthesis is required for the enhancement of long-term potentiation and long-term memory by spaced training. J Neurophysiol 87:2770-2777.

Serrano P, Yao Y, Sacktor TC (2005) Persistent phosphorylation by protein kinase $\mathrm{M} \zeta$ maintains late-phase long-term potentiation. J Neurosci 25:1979-1984.

Smith L, Smith JB (2002) Lack of constitutive activity of the free kinase domain of protein kinase $\mathrm{C}$ zeta. Dependence on transphosphorylation of the activation loop. J Biol Chem 277:45866-45873.

Standaert ML, Galloway L, Karnam P, Bandyopadhyay G, Moscat J, Farese RV (1997) Protein kinase C-zeta as a downstream effector of phosphatidylinositol 3-kinase during insulin stimulation in rat adipocytes. Potential role in glucose transport. J Biol Chem 272:30075-30082.

Sweatt JD (1999) Toward a molecular explanation for long-term potentiation. Learn Mem 6:399-416.

Whitlock JR, Heynen AJ, Shuler MG, Bear MF (2006) Learning induces long-term potentiation in the hippocampus. Science 313:1093-1097. 